\title{
A FOLLOW-UP SURVEY OF 1985 - 1996 GRADUATES OF THE AVIATION MANAGEMENT PROGRAM BACHELOR OF SCIENCE DEGREE AT SOUTHERN ILLINOIS UNIVERSITY CARBONDALE
}

\author{
Jose R. Ruiz, D. Scott Worrells, Robert W. Kaps, David A. NewMyer, \\ Joe Liberto, and Terry S. Bowman \\ Southern Illinois University Carbondale
}

\begin{abstract}
During 1997 and 1998, researchers conducted a follow-up study of graduates earning a Bachelor of Science Degree in Aviation Management (AVM) from the College of Applied Sciences and Arts (ASA) at Southern Illinois University Carbondale (SIUC). The purpose of the study was twofold: (a) to determine a demographic, educational, and occupational profile of the graduates and (b) to obtain an evaluation of the program in terms of the degree to which it helped graduates achieve their occupational and/or life goals.

The follow-up study population was composed of students who graduated from the aviation management degree program between 1985 and 1996. A population of 2,663 graduates was identified. A mail-in survey instrument was used to gather data for the follow-up study. Three mailings were conducted, resulting in 806 usable returns and a 31\% response rate.

Key findings of the study were: (a) eighty-six percent indicated that the degree was an asset that assisted them in achieving their occupational and/or life goals, (b) ninety percent indicated that they would recommend the program to others, (c) fifty-nine percent reported that they are employed within the aviation industry, (d) sixty-eight percent reported earning annual salaries in excess of $\$ 35,000.00$, and (e) sixty-three percent indicated that they were satisfied with their current levels of employment.
\end{abstract}

\section{INTRODUCTION}

Southern Illinois University Carbondale, through the College of Applied Sciences and Arts, currently offers the Bachelor of Science degree in Aviation Management. The AVM course curriculum consists of a set of major courses and a set of core courses in various aspects of aviation management.

The AVM program is offered at the SIUC campus and at various off-campus locations, mostly military bases, across the
United States. On-campus, the AVM program has its own office, teaching, and administrative staff. The Office of OffCampus Academic Programs (OCAP) provides administrative support for the AVM off-campus program through staff assigned to each location. However, all academic matters are left to the chair and faculty of the AVM program.

In the fall of 1994, OCAP began preparations to conduct a follow-up study of graduates of the AVM program at both onand off-campus sites. At that time, the 
director of OCAP organized preliminary discussions with the AVM department chair to set the scope and purpose of the study. Eventually, a mail survey questionnaire, reflecting the issues of greatest interest to the OCAP director and the AVM chair, was developed. A pilot study was conducted resulting in several revisions. Finally, in the spring of 1997, the first of three mailings consisting of questionnaire packets were mailed to 1985 through 1996 graduates of the AVM program. The following report deals specifically with the presentation of the data gathered from those graduates who responded to the questionnaire.

\section{PURPOSE OF THE STUDY}

The main purpose of the study was to determine the degree to which AVM baccalaureate graduates at SIUC on- and off-campus sites perceived the usefulness of the program in the demographic/ educational/occupational profile of the graduates.

The population selected for this study was composed of those who graduated from the program between 1985 and 1996.

\section{SIGNIFICANCE OF THE STUDY}

Administrators and educators generally agree that graduate follow-up surveys provide valuable information for program evaluation and improvement. The significance of this study was that it arose out of the specific needs of a program that has a wide range of topical coverage and reaches a large population of students over a substantial geographical area across the United States. The content of the survey instrument was derived from the suggestions of administrators and instructors in the AVM program. These suggestions were discussed in meetings that took place over a number of months, thus providing ample time for reflection between meetings. The content and purpose of the study reflects the issues and needs of the program as identified by the AVM faculty and staff. For example, the questionnaire item dealing with employment status listed general categories and specific segments within the management fields derived from the experience of the AVM administrative and educational staff members.

The previous considerations are related to the internal needs of the AVM program. There are also important external issues. For example, the Department of Defense-sponsored Military Installation Voluntary Education Reviews (MIVERS) conducted at military sites provide regular evaluation of SIUC off-campus AVM programs. That such an assessment, or graduate follow-up had not been taken at these locations was pointed out as a matter of "concern" by the 1995 MIVER revisit team (The American Council on Education, 1998, March 8-10). The revisit team, however, was informed that, at the time of their visit, the assessment project presented in this paper was underway. The team noted this project as a positive response to their previous recommendation. They viewed the direction of the assessment as an appropriate one, and made recommendations as to some of the ways the results could be used.

Another important use for the data collected in the present survey concerns the establishment of programs at new locations. Demographic and occupational data can provide critical justification for setting up a program at a particular geographical location. For example, an appropriate match between the occupations held by previous graduates of a program and the occupational resources of the proposed new educational site must be established to justify the institution of the program at the new site. 


\section{LITERATURE REVIEW}

The literature discussed can be arranged into three categories: (a) administrative guidance on graduate follow-up studies from state of Illinois and university sources, (b) prior, unpublished graduate follow-up studies of Aviation Management graduates, and (c) graduate follow-up studies done outside of SIUC.

\section{Administrative Guidance on Graduate Follow-up Studies}

In 1990, IBHE adopted a set of policies designed to improve the quality of undergraduate education (State of Illinois Board of Higher Education [IBHE], 1993, July 13). As part of the implementation of these policies, in 1993 the IBHE conducted its first baccalaureate graduate follow-up survey. Its rationale for the follow-up survey was that "information obtained from periodic surveys of graduates provides an important perspective in evaluating the effectiveness of the education provided by colleges and universities" (IBHE, 1993, July 13, p. 3). This first survey was intended to provide a baseline against which universities could evaluate the quality of their programs and identify areas for improvement. The IBHE planned to conduct two sets of 1-year out, 5-year out, and 10-year out surveys. Its purpose was to identify trends in employment, further education, and satisfaction of graduates. This information was then to be used by institutions in making program improvement decisions. The IBHE also intended to use the information as part of their state university review and program approval processes.

The Office of the Vice-President for Academic Affairs, in collaboration with the SIUC Foundation, completed two follow-up surveys of baccalaureate graduates: (a) a 1- year out survey of the class of 1991, (Southern Illinois University at Carbondale, 1994) and (b) a 5-year out survey of the class of 1994 (Southern Illinois University at Carbondale, 1998). The surveys were administered to graduates from universitywide programs. These surveys were conducted in compliance with IBHE policies previously discussed. The results available were not presented as studies but as sets of data tabulations compiled for inclusion in a statewide study undertaken by IBHE. The 1991 data set included personal characteristics of the graduates, further education, employment, and satisfaction with undergraduate education. The 1994 data set included attitudes toward the university campus, bachelor degree major, academic department, general education experiences, and academic and student support services.

\section{Prior Unpublished Graduate Follow-up Studies of Aviation Management Graduates}

In 1993, a follow-up study of AVM graduates from 1983 to 1990 was completed to fulfill the requirements of a master's degree (Skyles, 1993). The survey included both on-campus and off-campus graduates. The primary purpose of the study was to gather data that could be used to assess the program and lead to recommendations for improvement. The program assessment dealt with the major courses only. A secondary purpose was to develop an occupational and economic profile of the graduates. A few of the questions were similar to those in the instrument used in the present study, but the focus of the 1993 study is more general and less evaluative in design. Of particular interest to the present study were the questions on employment in various segments of the aviation industry, selection 
of the most and least valuable major courses, and salary level.

In 1981 and in 1987, the office of Off Campus Academic Programs conducted surveys of graduates from off-campus degree programs. The designs of the studies were virtually identical. Their purpose was twofold: (a) to develop a demographic profile of the graduates, including career directions and advancement since graduation and (b) to gather data useful in assessing whether the goals of the program were being met. Analysis of the data gathered consisted of the tabulation of frequencies and percentages.

All three of these studies share the same overall structural design: (a) development of a demographic/career profile and (b) program evaluation. This structure influenced the design of the current study. The main differences between the previous and present studies were in the scope of the design and the detail of the items in the survey instrument. The present study, like the 1993 AVM study, but unlike the OCAP studies, surveyed both on-campus and off-campus graduates. The present survey addressed several issues in the previous AVM study and similar issues in the OCAP studies but went into more detail in presenting options for subject responses. An important difference is that the present survey instrument asked respondents to identify their specific primary purposes for enrolling in the aviation management program and then stressed that program and course evaluations be made in consideration of their primary purpose for enrolling in the program.

\section{Graduate Follow-up Studies Done Outside of SIUC}

Two Ph.D. dissertations, both relevant and available, were examined. One was a follow-up study of elementary education graduates (Lippincott, 1981). The purpose of this study was to develop an instrument to collect data concerning the graduates' own perceptions of certain competencies and their perceptions of the effectiveness of the teacher training program at Missouri State University. Questions dealt primarily with teaching skills such as developing instructional objectives, motivating students, etc. Data analysis consisted of the tabulation of frequencies and percentages. Study conclusions resulted in the recommendation that the Elementary Training Program at Southwest Missouri State University should provide their students with more training in discipline, rapport with students, communicating ideas to children, and human relations.

A follow-up survey of graduates of arts and sciences was undertaken at the University of Arkansas to provide an employment profile of occupational progress, involvement in career planning, use of job search strategies, and completion of undergraduate and graduate education (Turner, 1991). A secondary purpose was to determine if additional programs and services were needed to assist students in gaining employment. Although most of the data was tabulated in the form of frequencies and percentages, an interesting, and appropriate, procedure was the use of chi-square analysis to determine the relationship between academic major and employment sector. The study made general recommendations for strengthening careerplanning activities and for additional educational experiences.

Although these two doctoral dissertations were not concerned with research in the domain of the present study, they are discussed here for two main reasons: (a) they offer additional support for the value of graduate follow-up surveys in the assessment and improvement of academic programs and services and (b) 
they indicate, to a degree, the diversity of approaches and methods in survey analysis that might influence future procedures.

\section{RESEARCH METHODOLOGY}

General preparations for the project included a number of meetings among affected SIUC program elements to set the parameters of the study and the general direction the study was to take. Over a period of several months, meetings were held to determine what questions would best serve the program's current and future needs. When the AVM faculty and staff were satisfied with the direction the survey was to take and with the specific questions that were to be asked, a survey instrument was devised. This instrument was tested in a pilot study.

\section{Pilot Study}

For the pilot study, a list of AVM program graduates from 1985 to 1996 was obtained from the Alumni Records Department of the SIUC Alumni Services. A survey packet consisting of a cover letter, survey questionnaire, comment sheet, and postage-paid reply envelope was sent out to each graduate in the pilot survey sample.

\section{Survey Instrument}

The questionnaire consisted of 22 items that asked for information in the following areas: (a) gender identification and race/ethnic background, (b) age at enrollment, at various stages of completion of the program, and now, (c) educational background and future interests, (d) occupational status, (e) prior and current salary levels, (f) evaluation of employment level, (g) future employment plans, (h) relationship between the baccalaureate degree and military advancement, (i) primary purpose for enrollment in the baccalaureate program, (j) evaluation of achievement of the primary purpose, and (k) evaluation of specific courses and the program in general in their usefulness in the attainment of the primary purpose.

\section{Reply card}

Since the respondents were anonymous, a way to know who returned the questionnaires was required, so that their names could be deleted from follow-up mailing lists. This was the purpose of the reply card.

\section{Subjects and Response Rate}

The subjects for this survey were identified in the Alumni Records Department of the SIUC Alumni Service, which keeps the most complete and current list of SIUC graduates. Alumni Services/SIUC Alumni Association sent a list of 2,663 on- and off-campus graduates of the AVM program from 1985 to 1996 to the SIUC Printing and Duplicating Services. Survey questionnaires were printed and mailed in May 1997. Second and third mailings were sent out in June 1997 and February 1998 to those who had not returned the reply card. The result for all three mailings was 841 returns, representing a $32 \%$ return rate, however 35 returns were unusable, resulting in a $31 \%$ usable return rate. Total mailed minus the undeliverable questionnaires gives the "sample frame," or the number of people who actually had the chance to participate in the study: $2663-52$ $=2611$. The response rate was calculated by dividing the number of returns by the 
sample frame: $841 / 2611=.33$. Similarly, the usable response rate was calculated by dividing the number of usable returns by the sample frame: $806 / 2611=.31$. It is not known how many of the undeliverable questionnaires were sent to on- or offcampus graduates. Thus a comparison between response rates for on- and offcampus graduates is not available. However, it is known that 332 of the respondents were from off-campus locations. See Figure 1.

\section{FINDINGS}

\section{Interpretation of the Data}

With the diversity of the AVM program graduate population: (a) on- and off-campus, (b) military and non-military, and (c) traditional and non-traditional, interpretation of the survey data collected was difficult. This difficulty was compounded by the 10-year time frame upon which the survey was conducted. For example, due to this extended time period, some respondents did not remember the courses they had taken and/or could not associate them to the present program curriculum. Three of the program's major courses were not offered at off-campus locations. These factors coupled with the anomalies unique to this survey, i.e., some respondents did not answer all questions, some respondents provided multiple responses to some questions, there were incorrect addresses, some surveys were not responded to, etc., increased the complexity of data interpretation.

\section{Demographic, Educational, and Occupational Profile}

The demographic profile is made up of: (a) gender, (b) race/ethnicity, and (c) economic characteristics of the survey respondents. The largest proportion of respondents was male $(93 \%)$ and white, non-Hispanic (88\%). A further breakdown reflecting the racial/ethnic make up of respondents is provided in Table 1.

The average age reported by respondents at enrollment was 25 years with an average age of 34 years at the time the survey was completed. The age span at enrollment, as reported by respondents, was 17 to 55 . At the time of the survey the age span was reported at 21 to 64 . The majority of respondents $(54 \%)$ reported attending the AVM program on-campus at SIUC. Although less than half of the respondents reported attending the program at offcampus locations it is interesting to note the geographic distribution of the off-campus program (see Figure 1). The data gathered indicated a $28 \%$ drop in military service over the period surveyed, with a majority of respondents distributed almost equally among the Air Force (29\%), Marine Corps (29\%), and Navy (38\%).

The AVM degree is awarded predicated upon the completion of, and often in concert with, an associate degree, or equivalent technical military coursework, or work experience. The AVM program has a requirement for 48 credit hours consisting of "core" and "major" coursework. The survey sought to determine how closely completion of the AVM program requirements coincided with completion of the baccalaureate degree requirements. To that end the data gathered indicated that the largest number of respondents reported completing the AVM program requirements coincidentally with the baccalaureate degree requirements between 1989 and 1992 (see Table 2).

When asked about current degree(s) held 802 of those participating provided a response to the categories offered: (a) Bachelors, (b) Masters, (c) Doctoral, and (d) Other. When asked about future academic 
plans, 465 participants responded. The majority of respondents indicated that they would be pursuing a masters degree. Table 3 illustrates these responses.

To determine the effectiveness of the AVM degree it was necessary to track student occupations "Prior to Enrollment", "During Enrollment", and in the "Now" category of the survey. Respondents were questioned on their employment status across the spectrum of the aviation industry. They were also asked if their employment status would be categorized as "Other Areas Outside the Aviation Industry". Table 4 shows the results of the data gathered from this question.

Prior to enrollment data indicate that the top three aviation industry employers were: (a) the Military $(45.0 \%)$, (b) Fixed Base Operators (6.3\%), and (c) Other Areas Within the Aviation Industry (3.9\%). Respondents indicated that these three sectors were the top three sources of employment during enrollment as well. However, the military employment figures decline by $5.8 \%$, while Fixed Base Operator numbers increase by $30 \%$, as do other areas within the aviation industry by $74 \%$. This shift in employment numbers from the military across the other sectors of the aviation industry is further emphasized by significant gains, during the enrollment period, in the following sectors: (a) NonProfit State or Local Agency by $350 \%$, (b) Airports by 150\%, and (c) Federal Government Agency by $73.9 \%$.

From the data gathered, $68 \%$ of those respondents indicated that it took an average of seven months after graduation to get a "degree-related" job. Some graduates $(4.5 \%)$ indicated that this was their first "aviation" job.

At the time of the survey, as is indicated by the "now" category of Table 4, the significance of the shift in employment is further emphasized. Survey data indicates that the top three employers within the aviation industry at this point were (a) the Airlines at $25.3 \%$, (b) the Military at $17.3 \%$, and (c) Other Areas Within the Aviation Industry at $15.0 \%$. Three sectors of the industry that showed a decline in employment numbers when comparing the "during enrollment" to the "now" responses were: (a) the Military by $59.2 \%$, (b) Fixed Base Operators by $43.1 \%$, and (c) NonProfit State or Local Agency by $18.5 \%$. When comparing the same periods, these numbers are overshadowed by the increases in employment numbers in the following three sectors of the industry: (a) the Airlines by $857.1 \%$, (b) the Manufacturers by 273.3\%, and (c) Other Areas Within the Aviation Industry by $120.3 \%$. As noted in Table 4 there were multiple responses in these categories.

Overall these data indicate that as the graduates entered the program and continued through the enrollment period, their primary source of employment was the military. During the enrollment period, a shift in employment began that culminated with the airlines as the major employer, as is reflected in the "now" category of Table 4.

The "Other Area Outside the Aviation Industry" must be addressed due to the numbers employed in this sector. Employment numbers prior to enrollment $(9.2 \%)$ and during enrollment $(8.3 \%)$ would place this sector of employment in the number two position for each of these enrollment categories. In the "now" category, respondents reported this sector as the number three employer of graduates. Prior to enrollment the difference between those employed by the military and those employed in other areas outside the aviation industry was $35.8 \%$. At the time the survey was completed this difference in sources of employment had dropped to $0.7 \%$.

Salary levels are always an important facet of an occupational profile. Respondent 
data indicated a shift in salary levels prior to graduation as related to salary levels after graduation. Salaries were reported to have increased by the majority of respondents after graduation. See Table 5. The relatively low salaries of respondents prior to graduation may be attributed to:

1. Traditional and on-campus students entering the program without employment or with part-time, supplemental, and minimum wage employment.

2. Non-traditional and off-campus students, predominantly military non-commissioned officers at the lower echelons of rank and pay.

For example, $55 \%$ of the respondents indicated they were in the lowest salary level prior to graduation. And, 87.7\% indicated annual salary levels prior to graduation below $\$ 34,000$, with the balance $(12.3 \%)$ indicating a salary level in excess of $\$ 34,000$. These numbers change significantly after graduation.

Respondents indicated that $33.3 \%$ of the AVM program graduates in the "after graduation category" were earning less than $\$ 34,000$ annually. This reflects a $54.4 \%$ drop in this salary level from the "prior to graduation" figures. As indicated by the survey $66.7 \%$ of the respondents reported "after graduation" salary levels in excess of $\$ 34,000$ for an increase in this category of $54.4 \%$.

Culminating the demographics, educational, and occupational profile was a question relating to student rationale for enrollment in the AVM program. Of the 801 responses to this question $44 \%$ indicated securing employment in the private sector of the aviation industry, $27 \%$ indicated career advancement in the private sector of the aviation industry, and $17 \%$ indicated career advancement in the military. See Table 6.

\section{Evaluation of the AVM Program}

For an evaluation of the AVM degree respondents were given an opportunity to evaluate core courses and major courses that make up the 48 credit hour program. Questions were formatted so that responses would indicate which courses were "most valuable" and "least valuable".

\section{Core Courses}

There were eight core courses in the AVM program curriculum evaluated by respondents. Survey data gathered indicated that, in descending order, respondents rated the following core courses as the top three most valuable: (a) Professional Development, (b) Labor-Management Problems, and (c) Work Center Management. A point to be made regarding the consistency of the data is that the first and second most valuable core courses, Professional Development and Labor-Management Problems, were also rated the lowest and next to lowest least valuable core courses. The top three least valuable core courses, in descending order, were: (a) Legal Aspects, (b) Data Interpretation, and (c) Independent Study and Work Center Management, reflecting a two way tie for third least valuable core course. Here again the data are consistent, reporting that Data Interpretation and Legal Aspects, selected as the first and second least valuable core courses, held down the lowest two positions in the most valuable core course category. However, the data reported were not always consistent. As can be seen in Table 7, Work Center Management was rated as the third most valuable and the third least valuable core course. 


\section{Major Courses.}

The AVM program curriculum consists of ten major courses. Three of these, The Air Traffic Control System, Aviation Safety Management, and National Airspace System, are not offered at offcampus locations. The most valuable major courses, in descending order, as reported by the respondents, were: (a) Airline Management, (b) Aviation Maintenance Management, and (c) Airport Management. The top three least valuable major courses, as reported, were: (a) Airport Planning, (b) General Aviation Operations, and (c) Aviation Maintenance Management. A similar trend in consistency from the core course evaluations pervades the major courses as well. For example, Airline Management and Airport Management, rated number one and number three most valuable major courses, respectively, were in the lower half of least valuable major courses. Airport Planning and General Aviation Operations, rated number one and number two, least valuable major courses, respectively, fell into the lower half of the most valuable major course category. However, Aviation Maintenance Management, the number two most valuable major course, was also rated as the number three least valuable major course. This finding may be explained by the demographic differences inherent to the onand off-campus student populations. Due to on-campus fight training, the majority of these students are typically geared toward a flight operations curriculum. In contrast, offcampus students report greater diversity in occupational interests. See Table 8.

Lastly, the participants were given an opportunity to answer three questions: the first was regarding their attitude towards the AVM degree, the second was whether or not they considered the degree an asset in achieving their employment goals, and the third was would they recommend the degree to others?

Regarding their attitude towards the AVM degree, and on a scale of 1 to 3 (1 being negative, 2 being neutral, and 3 being positive), a mean response of 2.65 was reported with a standard deviation of .6. This data reflects a decidedly positive respondent attitude toward the AVM degree.

The AVM degree was considered an asset in achieving employment goals by a predominant number of respondents. Of the 732 respondents providing input to this question $85.7 \%$ indicated the degree was an asset. An even larger number of the 794 respondents $(89.8 \%)$ indicated that they would recommend the degree to others.

\section{CONCLUSION}

Graduates of the B. S. in Aviation Management program at SIUC indicated that they highly valued the AVM degree program. For example, $85.7 \%$ considered the degree an asset towards achievement of their employment and career goals. Additionally, 89.8\% would recommend the Aviation Management degree to others. The data gathered provide insight of the value of the curriculum and employment within the civilian aviation industry. This is significantly illustrated by the huge increase in airline industry employment from prior to enrollment $(2.0 \%)$ to the time of the survey $(25.3 \%)$. Further indication of the program's success is that $43.8 \%$ of the respondents indicated employment within the private aviation industry was the primary purpose for enrollment; $46.9 \%$ indicated private aviation sector employment at the time of the survey. Another indication of the value of the curriculum to graduates was the large increase in annual salaries of respondents. Prior to graduation $87.7 \%$ of the respondents indicated annual salary levels at less than 
$\$ 34,000$, after graduation $66.7 \%$ reported salary levels equal to or in excess of this range.

From a demographic perspective, the B. S. in Aviation Management serves a white male population with a relatively high average age at enrollment (25). Employment data indicates that prior to matriculation the military was the major source of employment. At the time of the survey the data reflects an interesting shift in employment sectors. Following graduation the major source of employment was reported to be the airlines with the military sector closely behind. However, graduates indicated that the third largest source of employment was "Other Areas Outside the Aviation Industry" with a separation of $0.7 \%$ between the second and third most popular sources of employment. It is pertinent to conclude that the degree not only provides a bridge from military service to civilian aviation employment but also that the degree affords graduates opportunities outside of the aviation industry

The respondent's evaluation of the B. S. in Aviation Management curriculum "core courses" indicated that the courses "Professional Development" and "LaborManagement Problems" were considered most valuable and the courses "Legal Aspects of Aviation" and "Data Interpretation" were considered least valuable. As it relates to "major courses" in the curriculum "Airline Management" and "Aviation Maintenance Management" were considered most valuable, and the courses "Airport Planning" and "General Aviation Operations" were considered least valuable.

The survey results suggested areas for further analysis. One area in particular is the concept of beginning a longitudinal study of AVM graduates using the same methodology in each study. A second suggestion is that a comparison be made of on- and off-campus AVM responses, especially in the areas of respondent demographics and curriculum.

Using respondent's "least valuable" comments and faculty and administrator recommendations on results of the survey, the following changes are under consideration or have been made to the AVM program:

\section{Core Courses}

1. AVM 375-Legal Aspects of Aviation was moved from the core to the aviation major course listing.

2. ATS 383-Data Interpretation has been removed from the core course list.

3. ATS 364-Work Center Management has been revised to be more aviation oriented and has also been dropped altogether from the off-campus program. The new course number and title used on-campus is "AVM 302-Current Aviation Management Practices and Processes."

4. Independent Study Courses-These courses have been revised overall in terms of their direction and purpose, especially as they relate to the offcampus program where they are used most extensively.

5. ATS 416-Applications of Technical Information was revised and made more aviation oriented. It's new course number and title is "AVM 301-Aviation Management Writing and Communication."

\section{Major Courses}

The five major courses rated as "least valuable"; Airport Planning, General Aviation Operations, Aviation Maintenance Management, The Air Traffic Control System, and Aviation Industry Regulation, 
are currently being examined as to their content, validity, and "fit" in the on- and offcampus curriculum. As yet, no decisions have been made to their disposition. 


\section{REFERENCES}

American Council on Education: Center for Adult Learning and Educational Credentials. (1998). Military Installation Voluntary Education Review (MIVER): Final Report: MIVER revisit to Marine Corps Air Station (MCAS) Yuma, Arizona, 8-10 March 1998. (Washington, DC: Author).

Lippincott, C. E. (1981). Follow-up study of Southwest Missouri State University's elementary educatiion graduates. Unpublished doctoral dissertation, University of Arkansas.

Skyles, G.C. (1993). Aviation Management program graduate follow-up study on- offcampus from 1983 to 1990. Unpublished doctoral dissertation, Southern Illinois University, Carbondale.

Southern Illinois University at Carbondale. (1994). (Survey of graduates during calendar year 1991). Unpublished raw data.

Southern Illinois University at Carbondale. (1998). (Survey of graduates during calendar year 1991). Unpublished raw data.

State of Illinois Board of Higher Education. (1993, July 13). Item \#6: Undergraduate education policies: Implementation update. Springfield, IL: Author.

Turner, J.L. (1991). A follow-up survey of graduates of the J. W. Fulbright College of Arts and Sciences. Unpublished doctoral dissertation, University of Arkansas. 


\section{Table 1}

Race/Ethnic Identification

\begin{tabular}{lcc}
\hline Category & Frequency $(\mathrm{n}=797)$ & $\%$ \\
\cline { 2 - 3 } $\begin{array}{l}\text { American } \\
\text { Indian/Alaskan }\end{array}$ & 8 & 1.0 \\
Black & & \\
Non-Hispanic & 38 & 4.8 \\
$\begin{array}{l}\text { White } \\
\text { Non-Hispanic }\end{array}$ & 698 & 87.6 \\
$\begin{array}{l}\text { Asian/Pacific Islander } \\
\text { Indian Subcontinent }\end{array}$ & 25 & 3.1 \\
Hispanic & 28 & 3.5 \\
\hline
\end{tabular}

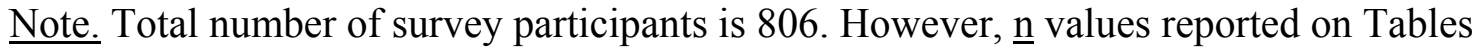
vary as all participants did not respond to all questions. 
Table 2

Completion of AVM Major Coursework and Baccalaureate Degree Requirements

\begin{tabular}{|c|c|c|c|c|}
\hline \multirow[b]{2}{*}{ Year } & \multicolumn{2}{|c|}{ Completion of Major $(\mathrm{n}=785)$} & \multicolumn{2}{|c|}{ Completion of Degree $(n=802)$} \\
\hline & Frequency & $\%$ & Frequency & $\%$ \\
\hline 1996 & 23 & 2.9 & 43 & 5.4 \\
\hline 1995 & 62 & 7.9 & 72 & 9.0 \\
\hline 1994 & 67 & 8.5 & 75 & 9.4 \\
\hline 1993 & 59 & 7.5 & 62 & 7.7 \\
\hline 1992 & 79 & 10.0 & 83 & 10.3 \\
\hline 1991 & 78 & 9.9 & 91 & 11.3 \\
\hline 1990 & 97 & 12.4 & 85 & 10.6 \\
\hline 1989 & 80 & 10.2 & 81 & 10.1 \\
\hline 1988 & 65 & 8.3 & 62 & 7.7 \\
\hline 1987 & 60 & 7.6 & 54 & 6.7 \\
\hline 1986 & 60 & 7.6 & 53 & 6.6 \\
\hline 1985 & 55 & 7.0 & 41 & 5.1 \\
\hline
\end{tabular}

Note. Total number of survey participants is 806 . However, $\underline{\mathrm{n}}$ values reported on Tables vary as all participants did not respond to all questions. 


\section{Table 3}

Present Degree Held and Future Academic Plans

\begin{tabular}{lcccc}
\hline & Degree Currently Held $(\mathrm{n}=802)$ & Future Academic Plans $(\mathrm{n}=465)$ \\
Degree & Frequency & $\%$ & Frequency & $\%$ \\
\hline Bachelor's & 705 & 87.9 & N/A & N/A \\
Master's & 92 & 11.5 & 368 & 79.1 \\
Doctoral & 5 & 0.6 & 52 & 11.2 \\
Other & N/A & N/A & 45 & 9.7 \\
\hline
\end{tabular}

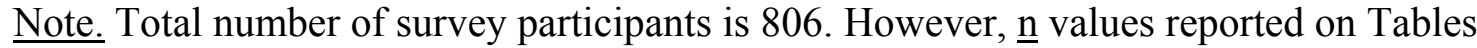
vary as all participants did not respond to all questions. 


\section{Table 4}

Employment Status

\begin{tabular}{|c|c|c|c|c|c|c|}
\hline \multirow[b]{2}{*}{ Industry Sector } & \multicolumn{2}{|c|}{$\begin{array}{c}\text { Prior to } \\
\text { Enrollment }\end{array}$} & \multicolumn{2}{|c|}{$\begin{array}{c}\text { During } \\
\text { Enrollment }\end{array}$} & \multicolumn{2}{|c|}{ Now } \\
\hline & Frequency & $\%$ & Frequency & $\%$ & Frequency & $\%$ \\
\hline Military & 357 & 45.0 & 336 & 42.3 & 137 & 17.3 \\
\hline $\begin{array}{l}\text { Federal Government } \\
\text { Agency }\end{array}$ & 23 & 2.9 & 40 & 5.0 & 68 & 8.6 \\
\hline $\begin{array}{l}\text { Non-Profit State or } \\
\text { Local Agency }\end{array}$ & 6 & 0.8 & 27 & 3.4 & 22 & 2.8 \\
\hline Airlines & 16 & 2.0 & 21 & 2.6 & 201 & 25.3 \\
\hline Fixed Base Operator & 50 & 6.3 & 65 & 8.2 & 37 & 4.7 \\
\hline Manufacturing & 13 & 1.6 & 15 & 1.9 & 56 & 7.1 \\
\hline Airports & 10 & 1.3 & 25 & 3.1 & 47 & 5.9 \\
\hline Self-Employed & 16 & 2.0 & 18 & 2.3 & 32 & 4.0 \\
\hline $\begin{array}{l}\text { Other Area Within } \\
\text { the Aviation Industry }\end{array}$ & 31 & 3.9 & 54 & 6.8 & 119 & 15.0 \\
\hline $\begin{array}{l}\text { Other Area Outside } \\
\text { the Aviation Industry }\end{array}$ & 73 & 9.2 & 66 & 8.3 & 132 & 16.6 \\
\hline
\end{tabular}

Note. Total number of survey participants is 806 . However, $\underline{n}$ values reported on Tables vary as all participants did not respond to all questions. For Table $4 \underline{n}=794$. 


\section{Table 5}

Gross Yearly Salary Levels Prior To and After Graduation

\begin{tabular}{ccccc}
\hline & Prior to Graduation $(\underline{\mathrm{n}}=709)$ & \multicolumn{2}{c}{ After Graduation $(\underline{\mathrm{n}}=778)$} \\
\cline { 3 - 4 } & Frequency & $\%$ & Frequency & $\%$ \\
Below $\$ 20,000$ & 388 & 54.7 & 80 & 10.3 \\
$\$ 20,000-\$ 34,000$ & 234 & 33.0 & 179 & 23.0 \\
$\$ 35,000-\$ 49,000$ & 70 & 9.9 & 254 & 32.6 \\
$\$ 50,000-\$ 64,000$ & 14 & 2.0 & 152 & 19.5 \\
Over $\$ 65,000$ & 3 & 0.4 & 113 & 14.5 \\
\hline
\end{tabular}

Note. Total number of survey participants is 806 . However, $\underline{\mathrm{n}}$ values reported on Tables vary as all participants did not respond to all questions. 


\section{Table 6}

Achievement of the Primary Purpose for Enrolling in the AVM Program

Primary Purpose for Enrollment

Frequency

Aviation Industry Employment

Federal government

81

State or municipal government

Private Industry

351

Other segment

Other reasons

Military advancement

Civilian employment after military service

Career advancement within the aviation industry

Salary increase

Self-development

Other reason

Note. Although respondents were asked to choose only one primary purpose, a number selected two or more. Total number of survey participants is 806 . However, $\underline{\mathrm{n}}$ values reported on Tables vary as all participants did not respond to all questions. For Table 6 $\underline{\mathrm{n}}=801$. 


\section{Table 7}

Evaluations of the Core Courses

Selected as Selected as

Most Valuable $(\mathrm{n}=736) \quad$ Least Valuable $(\mathrm{n}=700)$

Course

Frequency

$\% \quad$ Frequency

$\%$

Applications of

Technical Information

98

13.3

83

11.9

Work Center

Management

118

16.0

93

13.3

Labor-Management

Problems

172

23.4

62

8.9

Data Interpretation

19

2.6

96

13.7

Professional

Development

192

26.1

54

7.8

Fiscal Aspects

59

8.0

85

12.1

Legal Aspects

33

4.5

134

19.1

Independent Study

45

6.1

93

13.3

Note. Total number of survey participants is 806 . However, $\underline{\mathrm{n}}$ values reported on Tables vary as all participants did not respond to all questions. 


\section{Table 8}

Evaluations of the Major Courses

\begin{tabular}{|c|c|c|c|c|}
\hline \multirow[b]{2}{*}{ Course } & \multicolumn{2}{|c|}{$\begin{array}{c}\text { Selected as } \\
\text { Most Valuable }(\underline{\mathrm{n}}=706)\end{array}$} & \multicolumn{2}{|c|}{ 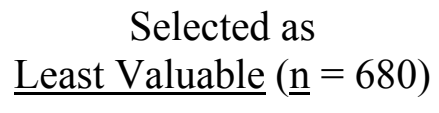 } \\
\hline & Frequency & $\%$ & Frequency & $\%$ \\
\hline Airport Planning & 41 & 5.8 & 178 & 26.1 \\
\hline $\begin{array}{l}\text { Aviation Industry } \\
\text { Regulation }\end{array}$ & 81 & 11.5 & 67 & 9.9 \\
\hline Airport Management & 107 & 15.2 & 49 & 7.2 \\
\hline Airline Management & 156 & 22.1 & 35 & 5.1 \\
\hline $\begin{array}{l}\text { General Aviation } \\
\text { Operations }\end{array}$ & 33 & 4.7 & 85 & 12.5 \\
\hline $\begin{array}{l}\text { Aviation Maintenance } \\
\text { Management }\end{array}$ & 138 & 19.5 & 71 & 10.4 \\
\hline $\begin{array}{l}\text { The Air Traffic Control } \\
\text { System }^{\mathrm{a}}\end{array}$ & 43 & 6.1 & 69 & 10.1 \\
\hline $\begin{array}{l}\text { Aviation Safety } \\
\text { Management }^{\mathrm{a}}\end{array}$ & 55 & 7.8 & 42 & 6.2 \\
\hline $\begin{array}{l}\text { Current Issues in } \\
\text { Aviation Management }\end{array}$ & 34 & 5.6 & 25 & 3.7 \\
\hline $\begin{array}{l}\text { National Airspace } \\
\text { System }^{\mathrm{a}}\end{array}$ & 18 & 2.6 & 59 & 8.7 \\
\hline
\end{tabular}

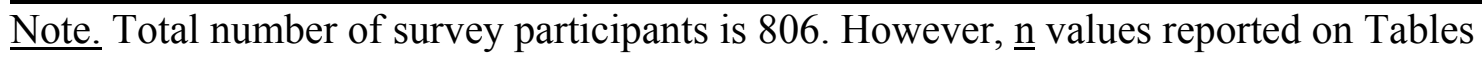
vary as all participants did not respond to all questions. ${ }^{a}$ Unavailable off-campus. 